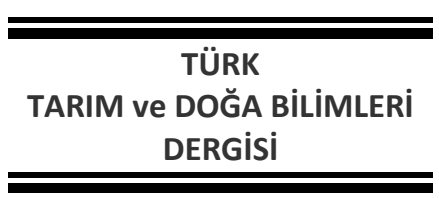

\title{
Tokat Kenti -Yeşilırmak Yakın Çevresinde Bulunan Rekreasyonel Alanlarda Kullanıcı Memnuniyetinin Belirlenmesi
}

\author{
Kübra YAZICI*, Aslı ARSLANTAŞ SAĞLAMER
}

Tokat Gaziosmanpaşa Üniversitesi, Ziraat Fakültesi, Bahçe Bitkileri Bölümü, Tokat, 60100

*Sorumlu yazar: k-yazici-karaman@hotmail.com

Geliş Tarihi: 24.05.2019

Düzeltme Geliş Tarihi: 27.08.2019

Kabul Tarihi: 29.08.2019

Özet

$\mathrm{Bu}$ araştırmada Tokat kent merkezinde kent halkının en sık kullandığı Yeşilırmak yakın çevresinde bulunan rekreasyonel alanlarının peyzaj öğeleriyle kullanıcı memnuniyetinin belirlenmesi amaçlanmıştır. 10 Ocak- 10 Mayıs 2019 tarihleri arasında yürütülen çalışmada; basit tesadüfi örnekleme yöntemine göre örnekleme hacmi \%5 hata payı ve \%95 güvenilirlikte 384 rekreasyonel alan kullanıcısı memnuniyeti belirlenmiştir. Kullanıcıların demografik yapısı dışında konum, ulaşılabilirlik, manzara, donatı elemanları, plastik objeler, arazi plastiği, tasarımı, bitki ve yabanı hayatı, etkinlik alanları, sınır öğesi, klimatik faktörler, su öğesi güvenlik gibi parametreler gruplara ayrılarak 62 adet rekreasyonel alanını doğru yansıtacak peyzaj öğeleri ile ilgili soru yöneltilmiştir. Likert ölçeğine göre puanlanan soruların ortalaması alınarak kullanıcıların rekreasyonel alanda memnuniyeti belirlenmiştir. Araştırma verilerinin değerlendirilmesinde IBM SPSS 22.0 programı kullanılmıştır. Sonuç olarak kullanıcıların en fazla memnun oldukları peyzaj özelliği grubunun konum, ulaşılabilirlik ve manzaradır. Rekreasyonel alanlarını kullanan 384 kullanıcının \% 21,6 'sı hafta içi \%72,7hafta sonu ve \%5,7'si ise hem hafta içi hem hafta sonu kullandığı görülmektedir.

Anahtar kelimeler: Rekreasyonel alan, kentsel peyzaj, ulaşılabilirlik, yeşil alan, Tokat.

\section{The Determination of User Satisfaction in the Recreational Areas Located in the Environs of Yeşilırmak / Tokat City}

\begin{abstract}
In this study, it was aimed to determine the user satisfaction of the recreation areas of Yesilırmak where are the most frequently used by the people in Tokat city. In the study conducted between 10 January and 10 May 2019 ; According to the simple random sampling method, the sampling volume was studied with a percentage of $5 \%$ error, 95\% reliability and total 384 users of the recreation area. Apart from the demographic structure of the users, 62 questions about recreational areas were divided into groups according to landscape elements like location, accessibility, landscape, reinforcement elements, plastic objects, land plastic, design, plant and wildlife, activity areas, boundary element, climatic factors, water element and security. The average score of the questions scored according to the Likert scale was determined and then the satisfaction of the users was evaluated. In the evaluation of the study data was used in IBM SPSS 22.0 program. In the results of the study; most of the users were satisfied the location, accessibility and landscape. It was seen that 384 users who use recreational areas were using $72.7 \%$ of weekdays $21.6 \%$ of them weekend and $5.7 \%$ of them use weekdays or weekends.
\end{abstract}

Key words: Recreation area, urban landscape, accessibility, open-green area, Tokat. 


\section{Giriş}

Kentsel çevrede daha iyi yaşam koşulları sağlamak amacıyla, açık alan planlaması içinde insandoğa, peyzaj bağlantısının önemli halkası olan, rekreasyonel anlamda da önemli bir rol oynayan yeşil alanlara ayrı bir önem vermek gerekmektedir (Müderrisoğlu ve Demir, 2004; Tilt, 2009; Gülgün ve ark. 2014, Yazici, 2018, Aşur, 2019). Kentlerde yer alan ve insanlar için psikolojik ve fizyolojik önem taşıyan kentsel açık alanların geçmişi, yerleşim birimlerinin tarihi kadar eskidir (Alpay ve ark., 2013; Berber ve Edgü, 2016). Geçmişten günümüze toplumların yaşam biçimine, kültürüne göre parklar ve yeşil alanlar fonksiyonel farklılıklar göstermişlerdir (Topalfakıoğlu, 2002; Yılmaz ve Irmak, 2012). Mevcut kentsel alanda, yeşil alanların önemi konusunda yapılan çalışmalara göre, yoğun trafik, gürültü ve kalabalık insanda sürekli gerilimlere neden olmaktadır. Yeşil mekanlara gitmek ise insanları rahatlatmakta ve çalışma verimini artırmaktadır (Dawson ve ark., 1997; Bowes ve Dawson, 1998; Birişci, 2012).

Açık yeşil alanlar insanlar tarafından boş zamanlarını değerlendirdiği en önemli alanlardır. Aksu ve Yılmaz (2018) Atatürk Üniversitesi yerleşkesinde merkezi açık yeşil alanda peyzaj tasarımı yapılan alanın yapım öncesi ve yapım sonrası kullanıc memnuniyetini ortaya koymak amacıyla yaptığı çalışmada, öğrenciler, öğretim görevlileri ve memurlar üzerinde farklı dönemlerde iki anket çalışması yürütmüşlerdir. Tasarım öncesi kullanıcıların alanı görsel $(74,2)$ ve bitkisel $(71,6)$ açıdan zayıf buldukları, tasarım sonrası ise memnuniyetin arttığı tespit edilmiştir. Katılımcıların $\% 75,6$ 'sının yapılan tasarımın gerekli olduğunu alanın üniversiteye itibar kazandırdığını belirttiğine dikkat çekmişlerdir. Trabzon kentinde bulunan müze bahçelerinin (Ayasofya Müzesi, Atatürk Köşkü Müzesi, Türk Eğitim Tarihi ve Teknoloji Müzesi) fiziksel peyzaj özelliklerini ve kullanıcıların bu özellikler üzerindeki memnuniyetini inceleyen Düzenli ve ark. (2017) puantaj yöntemi kullanılmışlardır. Elde ettikleri bulgulara göre en önemli sonuç müze bahçelerinin peyzaj özelliklerinin başarı düzeyi ile kullanıcı memnuniyeti arasında doğrusal bir ilişki olduğudur. Erdoğan ve ark. (2011) ise; turizm yatırımlarıyla hızlı kentleşmeye başlayan ve beraberinde yeni park alanları oluşan Konyaaltı'ndaki parklarda kullanılan donatı elemanlarının kullanıcı memnuniyetini yaptıkları anketlerle belirlemişlerdir. Anket sonuçlarına göre donatı elemanları içinde puanı en düşük olarak plastik elemanlar (kötü kategorisinde) ve puanı en yüksek olarak ise zemin döşeme elemanları (iyi) tespit edilmiştir. Emirgan Park'ının doğal ve tarihi kimliğini inceleyerek, zamanla fiziki değişiminin kullanıcı memnuniyeti üzerine etkileri Kart (2005) tarafından araştırıımıştır. Çalışma sonucunda Emirgan Parkı'nın doğal dokusunun korunması, mekânsal kalitesinin artırılması ve kullanıcı istek ve ihtiyaçları doğrultusunda revize edilmesi gerektiğini bildirmiştir. Ayrıca Emirgan Parkı'nın doğal koru özelliğinin bilinçsiz kullanımı sonucu tahribata uğradığı bildirilmiştir. Vural ve Yılmaz (2018) Erzurum'da 282 ortaokul öğrencisi üzerinde yaptığı araştırmada öğrencilerin büyük çoğunluğunun (\%59) serbest zamanlarını dış (açık) mekânlarda geçirmeyi tercih ettikleri ve kendini stresli hisseden bir arkadaşına en fazla $(\% 19,9)$ açık havada yürüme, gezme ve dolanma aktivitesini önerdiğini belirlemiştir.

Kentsel peyzajın temel taşı olan yeşil alanlar birçok işlevsel özelliğe sahiptir. Bunun içinde rekeasyonel alan olarak kullanımı en önemli işlevleri arasındadır (Aşur ve Alphan, 2017). Bu nedenle insanların stres attıkları doğa ile buluştuğu rekreasyonel alanların; çevre düzenlemeleri ve peyzaj özellikleri bakımından kullanıcısına hitap edip etmediğinin belirlenmesi gerekmektedir. Bu araştırmada; Tokat kentinde halk tarafından sıklıkla kullanılan Yeşilırmak'ın yakın çevresinde bulunan rekreasyonel alanların kullanıcı tarafından peyzaj özelliklerine memnuniyetlerinin belirlenmesi amaçlanmıştır. Elde edilen sonuçlar doğrultusunda kent için uygun olmayan kullanıcı tarafından değerlendirme de düşük puan alan peyzaj öğeleri belirlenmiştir. Elde edilen sonuçlara göre kullanıcıların memnun olmadıkları rekreasyonel alanlarda kalitenin yükseltilmesi ile ilgili öneriler getirilmiştir.

\section{Materyal ve Yöntem}

Tokat ili, Türkiye'nin Karadeniz Bölgesinde yer alan illerinden biridir. Kuzeyde Samsun, kuzeydoğuda Ordu, doğu ve güneyde Sivas, güneybatıda Yozgat ve batıda Amasya illeriyle Komşudur. illçelerinden Yeşilyurt ve Sulusaray iç̧ Anadolu Bölgesinde yer kalır. Yüzölçümü 10.072 km², Nüfusu 612.646 olup rakımı $623 \mathrm{~m}^{\prime}$ dir. Yıllık sıcaklık ortalaması en düşük $8.1^{\circ} \mathrm{C}$ en fazla $14.2{ }^{\circ} \mathrm{C}^{\prime}$ dir. Yıllık yağış ortalaması $381.7 \mathrm{~mm}$ ile $586.2 \mathrm{~mm}$ arası değişmektedir. Tokat; Yeşilırmak havzasının bereketli toprakları üzerine kurulmuş 6000 yıllık tarihi boyunca önemli ticaret ve kültür merkezi olmuş, 14 Devleti ve birçok beyliği içerisinde barındırmış önemli bir Anadolu şehridir. Birçok tarım ürünlerinin yetiştirilebildiği, coğrafi konum ve ikliminin uygunluğu, ülkenin her yerine ulaşımının 
kolay olması, Orta geçit kuşağında yer alması, süs bitkileri çeşitliliğinin sağlanması için gerekli koşulların bulunması ve sahip olduğu doğal kaynaklar nedeniyle vejetasyon süresi uzun olan illerden biridir (Yazici ve Gülgün Aslan, 2017).

Çalışmanın ana materyali; Tokat Yeşilırmak yakın çevresi oluşturmaktadır., Tokat halkının tercih ettiği bu alan; (Tarihi Taşhan'dan Yaklaşık 3,5 km uzaklıkta) ulaşımı açısından kolay olması, su öğelerinin varlığı ile günün her saatinde yararlanılabilen bir ortamdır. Yürüyüş yolları, bisiklet yolları, çocuk oyun parklarının bulunması, spor kompleksinin, Irmakta gondol gezintilerinin ve insanların piknik amaçlı kullanabilecekleri kameriye bulunması ayrıca çay bahçelerini de içinde barındırması ile halkın tercih ettiği rekreasyon alanlardır. Yeşilırmak kenarının şehir merkezine yakınlığını insanların bir vasıta olmadan da gidebileceği, her yaş grubundan insanların kolay ulaşabilmesini sağlamaktadır. Ayrıca Yeşilırmak yakın çevresi; etrafında bulunan Taş Köprüsü, Yeşilırmak Bilgi Evi ve Millet kıraathanesi gibi tarihi mekânlar ile insanların sosyal yaşamını olumlu yönde etkilemesinin yanı sıra bilgi birikimlerinin artmasına olanak sağlayan bir alandır (Şekil 1).

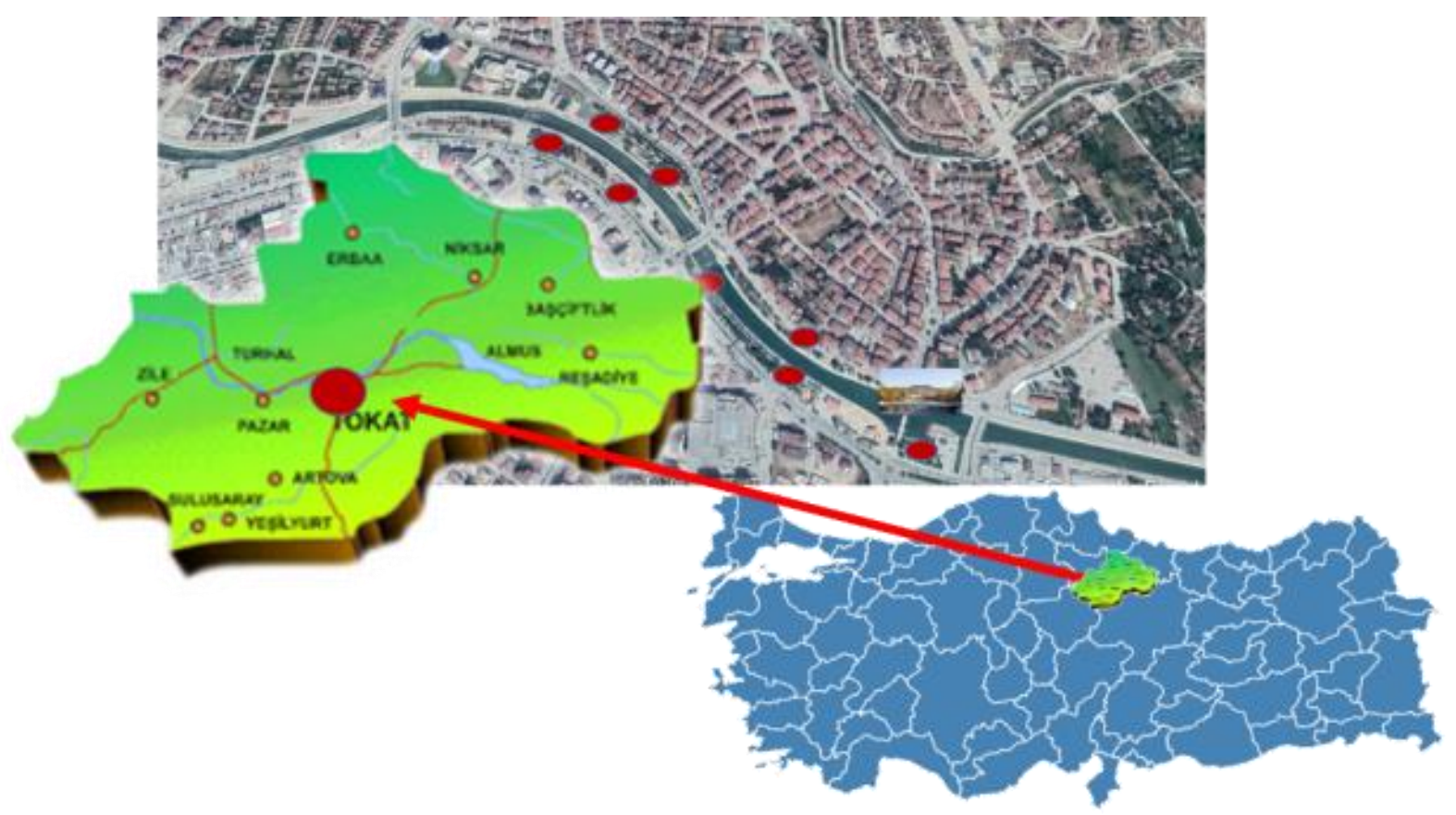

Şekil 1. Çalışma alanının harita ve uydu görüntüsü.

Tokat ili Merkez ilçesinde rekreasyonel alanlarda kullanıcı memnuniyetleri değerlendirmeyi amaçlayan bu çalışmada; Yeşilırmak kenarında bulunan parklar örnekleme alanı olarak seçilmiştir. Yapılan 384 anket çalışmaları SPSS (PC) paket programı kullanılarak İstatiksel analiz teknikleriyle değerlendirilmiştir. Çalışma 5 aşamada tamamlanmıştır.

1. aşama; Çalışma konusu ile ilgili web tabanlı kaynak taraması yapılmıştır,

2. aşamada; Yeşilırmak kenarındaki rekreasyonel alanların genel özellikleri tanımlanmış ve yeşil alan ve donatı elemanların mevcut durumu göz önünde bulundurularak; su varlığı bitki ve yaban hayatı, arazi plastiği, manzara, ulaşılabilirlik, tasarım, güvenlik ve konfor gibi genel özellikleri gruplandırılmıştır.

3. aşamada; anket soru formu oluşturulmuştur,

4. aşamada; Yeşilırmak kenarında rekreasyonel alan kullanıcılarına 384 anket yapılmıştır.

5. aşamada; Anket sonuçları değerlendirilerek çalışma tamamlanmıştır.

\section{Anket çalışması}

Anket formlarının oluşturulmasında bugüne kadar yapılmış olan çeşitli araştırmalardan yararlanılmıştır. Anket çalışmasında Aksu ve Yılmaz (2018) ve Düzenli ve ark. (2017) çalışmalarından 


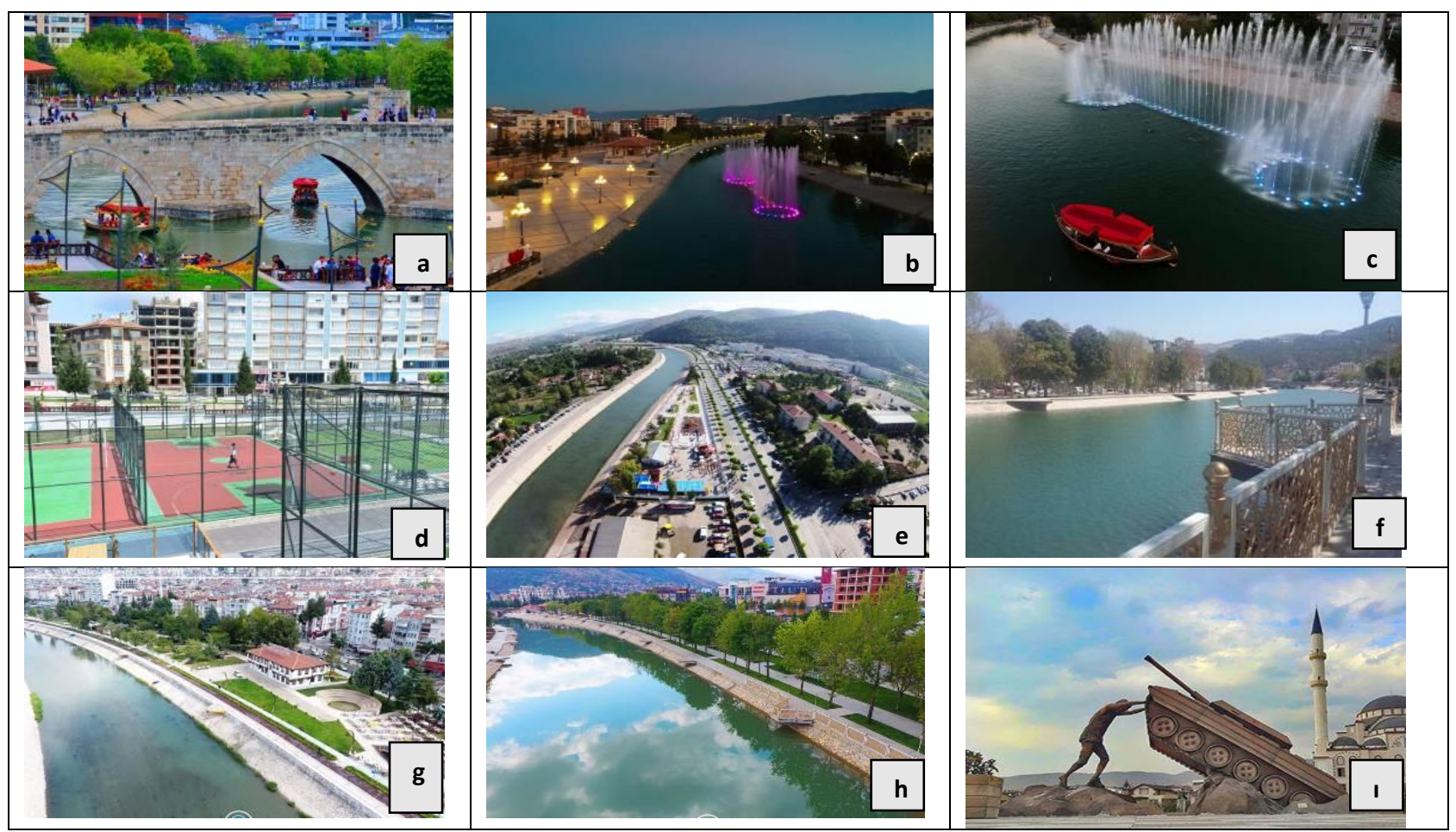

Şekil 2. Tokat Yeşilırmak kenarından görüntüler (a: Tarihi Taş Köprü b: Yeşilırmak ışıklı su gösterisi (gece), c: Yeşilırmak ışıklı su gösterisi (gündüz), d: Spor kompleksi, e: Yeşilırmak yakın çevresi genel görünüm, f: Yeşilırmak seyir terası, g: Yeşilırmak genel görüntüsü h: Yeşilırmak genel görüntüsü, ı: 15 Temmuz Şehitleri Anıtı) (Anonim, 2018).

\section{Örnekleme modeli}

$\mathrm{Bu}$ araştırmada incelenen veriler, Tokat Yeşilırmak kenarında bulunana rekreasyonel alanlarını kullanan kullanıcılar üzerinde yürütülen toplam 384 anket formunun doldurulması ile elde edilmiştir. Kişisel görüşme ile yürütülen anket soruşturması 10 Ocak-10 Mayıs 2019 tarihleri arasında hafta içi ve hafta sonları, yanıt verecek kişilere rastgele seçilerek yapılmıştır. Örnekleme modeli olarak basit tesadüfi örnekleme yöntemine göre örnekleme hacmi \%5 hata payı ve \%95 güvenilirlikte çalışılmıştır. Basit tesadüfi örneklemede evreni oluşturan her elemanın örneğe girme şansı eşittir. Dolayısıyla hesaplamalarda da her elemana verilecek ağırlık aynıdır (Arıkan, 2004). Örneklem büyüklükleri hesaplanırken Yazıcıoğlu ve Erdoğan (2004)'dan yararlanılmıştır. TUik, (2018)'e göre Tokat merkezinin toplam nüfusu 201.294 olarak belirlenmiştir Araştırmada kullanılan örnekleme yönteminde aşağıdaki formül kullanılmıştır.

Formül $n=N t^{2} p q$
$\mathrm{n}$ : Örnek hacmi
N: Toplam Tokat Merkez nüfusu
p: Gerçekleşme sıklığı
q: Gerçekleşmeme sıklığı
t: Belirli bir anlamlılık düzeyi (1.96)

\section{Verilerin değerlendirilmesi}

Demografik yapı ve kullanım zamanı soruları dışında kalan tüm anket soruları (62 soru) 5'li Likert ölçeği ile değerlendirilmiştir. Elde edilen puanlama sonrası standart sapma, ortalama değer anketlerin aralık sınırlarının hesaplanması aralık katsayı hesaplamasıyla hesaplanmış ve 0.60 , ortalama ile karşılaştırmalar esas olmak üzere değerlendirme yapılmıştır. Araştırma verilerinin analizinde frekans, yüzde, ortalama ve standart sapma gibi tanımlayıcı istatistiklerden yararlanılmış ve IBM SPSS 22.0 programı kullanılmıştır.

\section{Bulgular ve Tartışma}

Tokat Yeşilırmak kenarında bulunan rekreasyonel alanlarını kullanan 384 kullanıcıya anket 
yapılmıştır. Ankete katılanların 51,3 (197 kişi) kadın ve \%48,7'si (187 kişi) erkektir. Ankete katılanların 93' ü kent merkezinde yaşayanlar iken \%7'si I kent dışından gelen ziyaretçilerdir. Ankete katılanların büyük çoğunluğu 16-29 yaş (175 kişi) ve 30-45 yaş
(143 kişi), 46-60 yaş (52 kişi) ve 60 yaş üzeridir (14 kişi) (Çizelge 1). Ankete katılan kullanıcıların eğitim durumu ise; 57 kişi ilköğretim, 102 kişi lise, 190 kişi üniversite ve 35 kişi lisansüstü eğitim görmüştür.

Çizelge 1. Ankete katılan kullanıcıların demografik frekans değerleri

\begin{tabular}{llc}
\hline Tokat Yeşilırmak kenarında bulunan rekreasyonel alan kullanıcıları & \multicolumn{1}{c}{$\%$} \\
\hline \multirow{3}{*}{ Cinsiyet } & Kadın & 51.3 \\
& Erkek & 48.7 \\
\cline { 2 - 3 } & Toplam & 100 \\
\hline \multirow{3}{*}{ Yaş } & $16-29$ & 45.6 \\
& $30-45$ & 37.2 \\
& $46-60$ & 3.6 \\
\hline \multirow{3}{*}{ Kullanıcı ikametgâh } & 40 yaş üzeri & 93.0 \\
& Merkez & 7 \\
\hline & Tokat kenti dışı & 100 \\
\cline { 2 - 3 } & Toplam & 14.8 \\
Eğitim & ilköğretim & 26.6 \\
& Lise & 49.5 \\
& Lisans & 9.1 \\
\hline
\end{tabular}

\section{Rekreasyonel alanin kullanici tarafindan tercih edildiği günler}

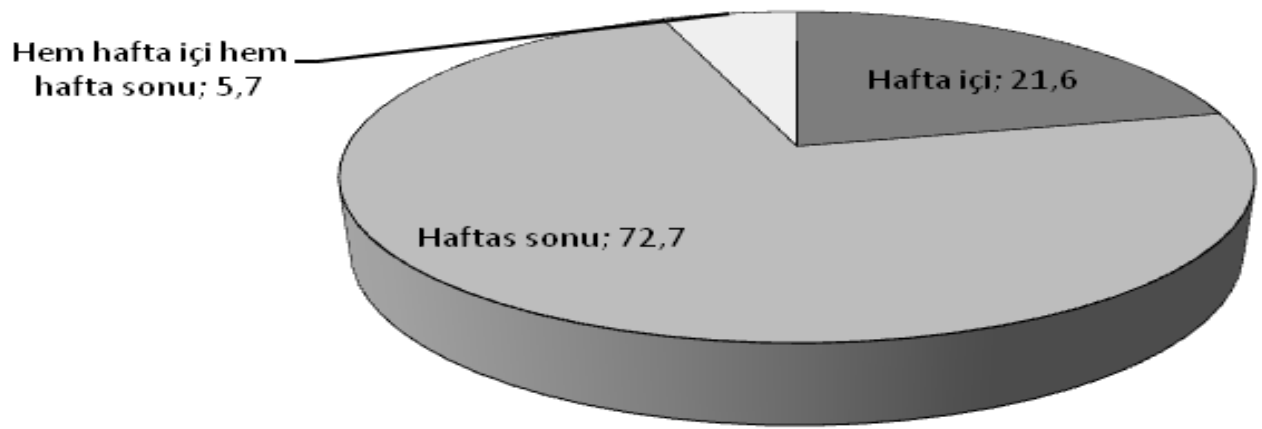

Şekil 3. Rekreasyonel alanın kullanıcı tarafından tercih edildiği günler.

\section{Kullanım zamanı}

Tokat Yeşilırmak kenarında bulunan rekreasyonel alanlarını kullanan 384 kullanıcının \% 21,6 's hafta içi $\% 72,7$ hafta sonu ve $\% 5,7$ 'si ise hem hafta içi, hem hafta sonu kullanmaktadır (Şekil 3). Kullanıcıların yüzde 52,3 'si akşam vakitlerinde \%31,3'ü öğle vakitlerinde \% 9,4'ü Öğle ve akşam vakitlerinde Yeşilırmak kenarında vakit geçirmektedir (Şekil 4).

\section{Memnuniyet sorusuna ilişkin bulgular}

Konum ile ilgili sorulara verilen yanıtlar dikkate alınan kıyaslama ortalamasının üstünde yer almaktadır. Buna göre 1. Anket sorusu "Yeşilırmak kenarındaki rekreasyonel alanlar konum olarak 
ziyaret edilebilirliği kolaydır" 1.15 ortalamaya sahiptir. 2. Soruya "Yeşilırmak kenarındaki rekreasyonel alanlar şehir merkezine yakındır" verilen puanın ortalaması 1,14'tür. Ankete katılan katılımcılar tüm sorulan sorular içinde "Yeşilırmak kenarındaki rekreasyonel alanlarda yürüyüş yolu vardır" 8 . soruya 1,23 ortalama ile en yüksek puanı vermişlerdir. Ulaşılabilirlik grubu içinde yer alan 3 ve10. Sorulara verilen puan ortalamaları kıstas olarak ele alınan ortalamanın üstündedir. 11 . soru "Yeşilırmak kenarındaki rekreasyonel alanların manzarası vardır" verilen yanıt ortalaması 0,97'dir. 12. Soru "Yeşilırmak kenarındaki rekreasyonel alanların manzarası gün boyu canlıdır" verilen yanıt ortalaması 0,70 ve 13. Soru "Yeşilırmak kenarındaki rekreasyonel alanlarda yeşil alan vardır" verilen kullanıcı yanıtı ortalaması 0,89'dur. 14 soru dışında diğer sorulara verilen yanıtlar memnuniyet ortalamanın üstündedir. Elde edilen sonuçlar Tarakci ve ark., (2017) yaptığı çalışmada belirttiği manzara etkisinin alan kullanımında önemli olduğunu desteklemektedir. Tasarım grubunda yer alan sorulara kullanıcıların verdiği puan iki soru dışında kıstas alınan memnuniyet ortalamasına göre düşüktür. 16. Soru “ Mevcut yeşil alan Yeşilırmak kenarındaki rekreasyonel alanların ziyaretini artırabilir niteliktedir" verilen yanıtların ortalaması 0,65'dır. 20. soruya "Yeşilırmak kenarındaki rekreasyonel alanların yeni hali tarihi objelerin görsel kalitesini artırmıştır" verilen puanın ortalaması ise 0,60'dır (Çizelge

2).

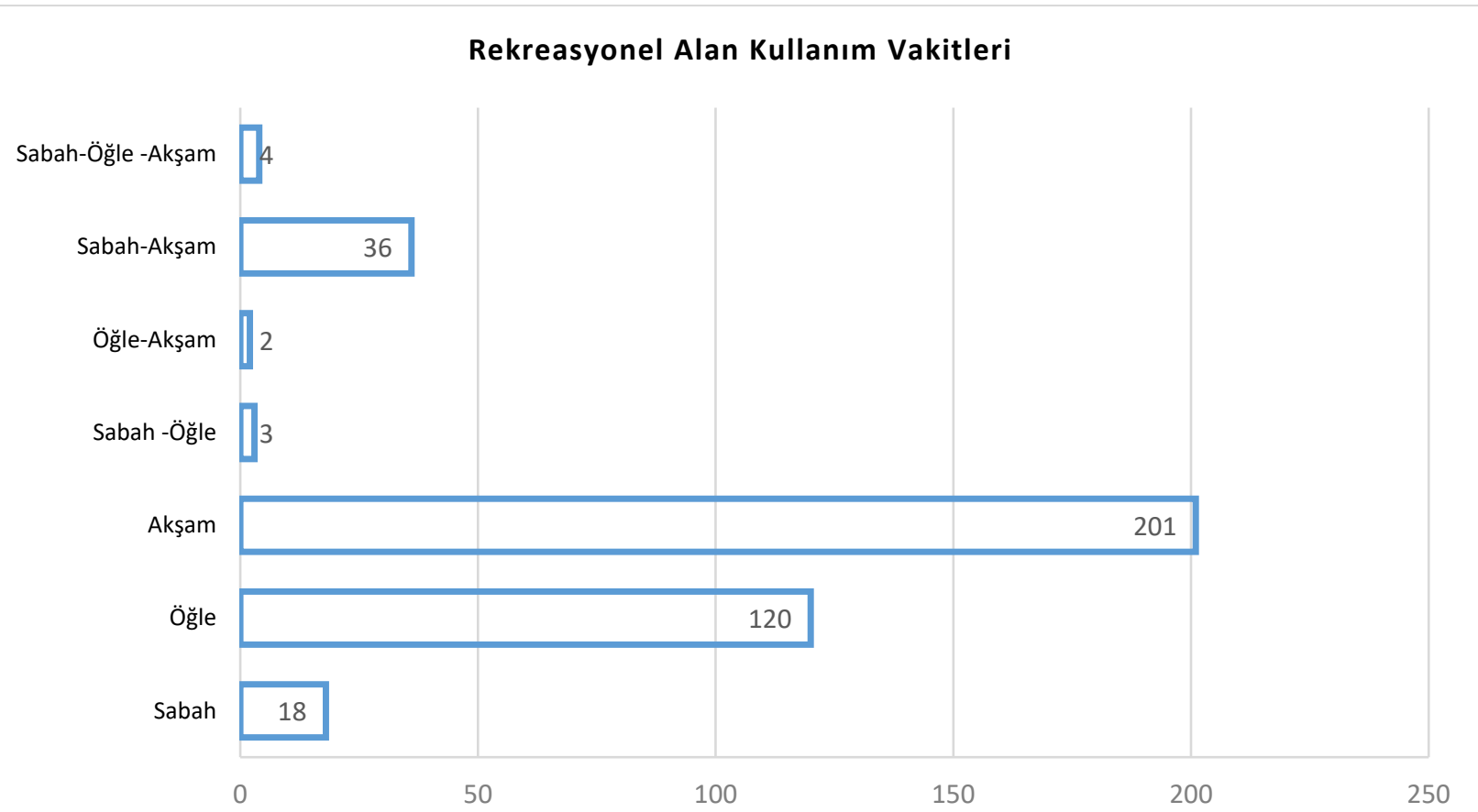

Şekil 4. Rekreasyonel alanın kullanıcı tarafından tercih ettiği gün içindeki vakitler.

21. soruya " Yeşilırmak kenarındaki rekreasyonel alanlar toprak ve eğim açısından kullanıma uygundur" verilen puan ortalaması 0,62'dir. Kullanıcılar 22. soruda verdikleri puan değerlendirildiğinde merdiven ve rampalardan memnun değillerdir (Çizelge 2). Sınır öğesi grubunda kullanıcılara sorulan 22. sorunun puan ortalaması "Yeşilırmak kenarındaki rekreasyonel alanları sınırlayan yapısal peyzaj elemanları vardır" kıstas alınan memnuniyet ortalamasından düşüktür (Çizelge 2). Etkinlik mekânlarda 24, 28 ve 29. sorular değerlendirilen ortalamanın üstünde puana sahiptir. 24. soruya "Yeşilırmak kenarındaki rekreasyonel alanlarda etkinlik alanları vardır" verilen puan ortalaması 0,71'dir. 28. soruya "Yeşilırmak kenarındaki rekreasyonel alanlarda dinlenilecek mekanlar vardır" ise verilen puan ortalaması 0,80 ve 29. soru "Yeşilırmak kenarındaki rekreasyonel alanlar kalabalık gruplar halinde kullanıma uygundur" sorusuna verilen puan $0,67^{\prime}$ dir. Elde edilen sonuç ile Müderrisoğlu'nun (2002) yaptığı çalışmada mekanda kalabalık algısı ve kullanıcı memnuniyeti üzerine yapılan çalışmada daha önceleri kalabalık ile memnuniyetin ters orantılı olduğu varsayılırken son zamanlarda kalabalık algısının memnuniyetsizlik değil yer değiştirme ya da beklenti değiştirme şeklinde 
değiştiği sonucunu desteklemektedir (Whittaker ve Shelby, 1988; Gülgün ve ark., 2015; Uzun, 2019). Yöneticilerin mevcut mekanların kullanımlarını iyileştirmesi ve alternatif mekanlar oluşturması gerekliliği vurgulanmıştır. Kullanıcılar klimatik faktörlere göre uygun malzeme kullanılmadığını düşünmektedir. Donatı elemanlarında kullanıcıların verdikleri puan doğrultusunda 37. soru "Yeşilırmak kenarındaki rekreasyonel alanlarda aydınlatma elemanları yeterlidir" sorusuna kıstas alınan ortalamanın üstünde cevap verilmiştir. Rekreasyonel alanda bulunan aydınlatmadan anket katılımcısı memnundur. Topalfakıoğlu (2002) tarafından Çamlıca ve Fethi Paşa koruları ile Doğancılar parkının memnuniyeti derecesinin belirlenmesinde; Fethi Paşa korusunun güzel bir manzaraya sahip olduğu ve kolay ulaşılabilir olduğu için yoğun kullanıcı aldığı bildirilmiştir. Büyük Çamlıca korusunun da doğal güzelliği ve sahip olduğu donatılar nedeniyle büyük ilgi gördüğü tespit edilmiştir. Fakat yoğun kullanıcı sayısı üzerine oturum alanlarının yetersiz olduğu kullanıcılar tarafından bildirilmiştir. Doğancılar parkının ise korular kadar doğal güzelliğe sahip olmasa da yerleşme biriminin içinde yer aldığı için kullanıcı aldığı fakat korular kadar yoğun kullanıma sahip olmadığı belirlenmiştir. Yapılan bu çalışma Topalfakıoğlu (2002) ile paralel sonuçları vermiştir. 45. soruya "Yeşilırmak kenarındaki rekreasyonel alanlarda hareketli su öğesi (yapay şelale/fıskiye) ortamın prestijini artırmaktadır" verilen puanların ortalaması 0,89'dur. 47.soru "Yeşilırmak kenarındaki rekreasyonel alanların eski haline göre ırmak suyu miktarı artmıştır" verilen ortalama 0,79'dur.48. soru "Yeşilırmak kenarındaki rekreasyonel alanların eski haline göre suyu daha temizdir" ise kıstas alınan ortalamanın üstünde bir değer almıştır $(0,76)$. Elde edilen sonuçlar Tarakci ve ark., (2017) yaptıkları çalışmayı desteklemektedir.

Çizelge 2. Tokat Yeşilırmak kenarındaki rekreasyonel alanlara ait soruların değerlendirilmesi

\begin{tabular}{|c|c|c|c|c|}
\hline \multicolumn{3}{|c|}{ Tokat Yeşilırmak kenarındaki rekreasyonel alanlara ait soruların değerlendirilmesi } & ஸ் & ப் \\
\hline \multirow[t]{2}{*}{ KONUM } & 1 & $\begin{array}{l}\text { Yeşilırmak kenarındaki rekreasyonel alanlar konum olarak ziyaret } \\
\text { edilebilirliği kolaydır. }\end{array}$ & 1.02 & 1.15 \\
\hline & 2 & Yeşilırmak kenarındaki rekreasyonel alanlar şehir merkezine yakındır. & 1 & 1.14 \\
\hline \multirow{8}{*}{$\begin{array}{l}\text { ULAŞIM } \\
\text { ERIŞiLEBILIRLIK }\end{array}$} & 3 & $\begin{array}{l}\text { Yeşilırmak kenarındaki rekreasyonel alanlara tüm kullanıcı grupları } \\
\text { (engelli/çocuk/yaşlı) kolaylıkla ulaşabilir. }\end{array}$ & 1.01 & 0.93 \\
\hline & 4 & Yeşilırmak kenarındaki rekreasyonel alanlara karayolu ulaşmaktadır. & 0.95 & 1.21 \\
\hline & 5 & $\begin{array}{l}\text { Yeşilırmak kenarındaki rekreasyonel alanlardan diğer toplumsal } \\
\text { mekanlara ulaşım kolaydır. }\end{array}$ & 0.88 & 1.16 \\
\hline & 6 & Yeşilırmak kenarındaki rekreasyonel alanlarda yeterli otopark mevcuttur. & 1.36 & -0.25 \\
\hline & 7 & $\begin{array}{l}\text { Yeşilırmak kenarındaki rekreasyonel alanlardan etkinlik alanlarına } \\
\text { ulaşmak kolaydır. }\end{array}$ & 0.84 & 0.94 \\
\hline & 8 & Yeşilırmak kenarındaki rekreasyonel alanlarda yürüyüş yolu vardır. & 0.85 & 1.23 \\
\hline & 9 & $\begin{array}{l}\text { Yeşilırmak kenarındaki rekreasyonel alanların yolları tüm kullanıcı grupları } \\
\text { (engelli/çocuk/yaşlı) için uygundur. }\end{array}$ & 1.09 & 0.77 \\
\hline & 10 & $\begin{array}{l}\text { Yeşilırmak kenarındaki rekreasyonel alanların eski haline göre } \\
\text { erişilebilirliği artmıştır. }\end{array}$ & 1.09 & 0.98 \\
\hline \multirow{4}{*}{ MANZARA } & 11 & Yeşilırmak kenarındaki rekreasyonel alanların manzarası vardır. & 0.94 & 0.97 \\
\hline & 12 & $\begin{array}{l}\text { Yeşilırmak kenarındaki rekreasyonel alanların manzarası gün boyu } \\
\text { canlıdır. }\end{array}$ & 1.55 & 0.70 \\
\hline & 13 & Yeşilırmak kenarındaki rekreasyonel alanlarda yeşil alan vardır. & 1.04 & 0.89 \\
\hline & 14 & $\begin{array}{l}\text { Yeşilırmak kenarındaki rekreasyonel alanlarda yeşil alan boyutları } \\
\text { yeterlidir. }\end{array}$ & 1.26 & 0.36 \\
\hline \multirow{4}{*}{ TASARIM } & 15 & $\begin{array}{l}\text { Yeşilırmak kenarındaki rekreasyonel alanlarda yeşil alan tasarımı } \\
\text { düzgündür. }\end{array}$ & 1.15 & 0.46 \\
\hline & 16 & $\begin{array}{l}\text { Mevcut yeşil alan Yeşilırmak kenarındaki rekreasyonel alanların ziyaretini } \\
\text { artırabilir niteliktedir. }\end{array}$ & 1.08 & 0.65 \\
\hline & 17 & $\begin{array}{l}\text { Yeşilırmak kenarındaki rekreasyonel alanlardaki yeşil alan donatı } \\
\text { tasarımları ortamla uyumludur. }\end{array}$ & 1.16 & 0.51 \\
\hline & 18 & Yeşil alanlardaki bitki türleri Yeşilırmak kenarındaki rekreasyonel alanların & 1.10 & 0.56 \\
\hline
\end{tabular}


itibarını artıracak niteliktedir.

19

Yeşilırmak kenarındaki rekreasyonel alanlarda donatı elemanları estetiktir.

$1.27 \quad 0.47$

20

Yeşilırmak kenarındaki rekreasyonel alanların yeni hali tarihi objelerin görsel kalitesini artırmıştır.

Çizelge 3. Tokat Yeşilırmak kenarındaki rekreasyonel alanlara ait soruların değerlendirilmesi (devamı)

\begin{tabular}{|c|c|c|c|c|}
\hline \multicolumn{3}{|c|}{ Tokat Yeşilırmak kenarındaki rekreasyonel alanlara ait soruların değerlendirilmesi } & $\ddot{\sim}$ & ذّ \\
\hline \multirow{2}{*}{ ARAZi PLASTiĞi } & 21 & $\begin{array}{l}\text { Yeşilırmak kenarındaki rekreasyonel alanlar toprak ve eğim açısından } \\
\text { kullanıma uygundur. }\end{array}$ & 1.06 & 0.62 \\
\hline & 22 & $\begin{array}{l}\text { Yeşilırmak kenarındaki rekreasyonel alanlarda kullanılan merdiven ve rampa } \\
\text { kullanıma uygundur. }\end{array}$ & 1.12 & 0.45 \\
\hline SINIR ÖGESI & 23 & $\begin{array}{l}\text { Yeşilırmak kenarındaki rekreasyonel alanları sınırlayan yapısal peyzaj } \\
\text { elemanları vardır. }\end{array}$ & 1.07 & 0.30 \\
\hline \multirow{9}{*}{$\begin{array}{l}\text { ETKINLIK } \\
\text { MEKÂNLAR }\end{array}$} & 24 & Yeşilırmak kenarındaki rekreasyonel alanlarda etkinlik alanları vardır. & 1.07 & 0.71 \\
\hline & 25 & Yeşilırmak kenarındaki rekreasyonel alanlarda etkinlik alanları yeterlidir. & 1.20 & 0.28 \\
\hline & 26 & Yeşilırmak kenarındaki rekreasyonel alanlarda oturma alanları yeterlidir. & 1.24 & 0.27 \\
\hline & 27 & Yeşilırmak kenarındaki rekreasyonel alanlarda yeme-içme alanları yeterlidir. & 1.29 & 0.24 \\
\hline & 28 & Yeşilırmak kenarındaki rekreasyonel alanlarda dinlenilecek mekanlar vardır. & 1.10 & 0.80 \\
\hline & 29 & $\begin{array}{l}\text { Yeşilırmak kenarındaki rekreasyonel alanlar kalabalık gruplar halinde } \\
\text { kullanıma uygundur. }\end{array}$ & 1.15 & 0.67 \\
\hline & 30 & Yeşilırmak kenarındaki rekreasyonel alanlarda bisiklet yolları vardır. & 1.21 & 0.50 \\
\hline & 31 & Yeşilırmak kenarındaki rekreasyonel alanlarda yeterli oyun parkı vardır. & 1.19 & 0.55 \\
\hline & 32 & $\begin{array}{l}\text { Yeşilırmak kenarındaki rekreasyonel alanlardaki oyun parkları çocukların can } \\
\text { sağıı̆̆ı ve güvenliği açısından uygundur. }\end{array}$ & 1.36 & -0.2 \\
\hline \multirow{3}{*}{$\begin{array}{l}\text { KLIMATIK } \\
\text { FAKTÖRLER }\end{array}$} & 33 & Yeşilırmak kenarındaki rekreasyonel alanlar mevsimsel kullanıma uygundur. & 1.71 & 0.2 \\
\hline & 34 & $\begin{array}{l}\text { Yeşilırmak kenarındaki rekreasyonel alanlardaki etkinlik alanları iklimsel } \\
\text { faktörlere uygun tasarlanmıştır. }\end{array}$ & 1.26 & -0.3 \\
\hline & 35 & $\begin{array}{l}\text { Yeşilırmak kenarındaki rekreasyonel alanlar kışın karlanma ve buzlanma } \\
\text { açısından kullanıma uygundur. }\end{array}$ & 1.24 & -0.21 \\
\hline \multirow{8}{*}{ DONATI } & 36 & $\begin{array}{l}\text { Yeşilırmak kenarındaki rekreasyonel alanlarda çardak ve örtü elemanı } \\
\text { kullanılmıştır. }\end{array}$ & 1.08 & 0.47 \\
\hline & 37 & $\begin{array}{l}\text { Yeşilırmak kenarındaki rekreasyonel alanlarda aydınlatma elemanları } \\
\text { yeterlidir. }\end{array}$ & 1.52 & 0.78 \\
\hline & 38 & Yeşilırmak kenarındaki rekreasyonel alanlarda gölge alanlar yeterlidir. & 1.12 & 0.47 \\
\hline & 39 & $\begin{array}{l}\text { Yeşilırmak kenarındaki rekreasyonel alanlarda zemin kaplaması ortamla } \\
\text { uyumludur. }\end{array}$ & 1.08 & 0.54 \\
\hline & 40 & Yeşilırmak kenarındaki rekreasyonel alanlarda yeterli çim alan vardır. & 1.15 & 0.50 \\
\hline & 41 & Yeşilırmak kenarındaki rekreasyonel alanlarda plastik nesneler vardır. & 1.02 & 0.56 \\
\hline & 42 & $\begin{array}{l}\text { Yeşilırmak kenarındaki rekreasyonel alanlarda yeterli sayıda çöp kutusu } \\
\text { bulunmaktadır. }\end{array}$ & 1.21 & 0.46 \\
\hline & 43 & Yeşilırmak kenarındaki rekreasyonel alanların çevre temizliği yeterlidir. & 1.30 & 0.25 \\
\hline \multirow{5}{*}{ SU ÖGESi } & 44 & Yeşilırmak kenarındaki rekreasyonel alanlarda su öğesine yer verilmiştir. & 1.14 & 0.80 \\
\hline & 45 & $\begin{array}{l}\text { Yeşilırmak kenarındaki rekreasyonel alanlarda hareketli su öğesi (yapay } \\
\text { şelale/fıskiye) ortamın prestijini artırmaktadır. }\end{array}$ & 1.15 & 0.89 \\
\hline & 46 & $\begin{array}{l}\text { Yeşilırmak kenarındaki rekreasyonel alanlarda yüzdürülen sandal sayısı } \\
\text { yeterlidir. }\end{array}$ & 1.23 & 0.37 \\
\hline & 47 & $\begin{array}{l}\text { Yeşilırmak kenarındaki rekreasyonel alanların eski haline göre ırmak suyu } \\
\text { miktarı artmıştır. }\end{array}$ & 1.16 & 0.79 \\
\hline & 48 & Yeşilırmak kenarındaki rekreasyonel alanların eski haline göre suyu daha & 1.26 & 0.76 \\
\hline
\end{tabular}


temizdir.

\begin{tabular}{ll}
\hline Aytaç ve Uzun (2015)’e göre Düzce kent & soru “Yeşilırmak kenarındaki rekreasyonel alanlarda \\
merkezindeki yaya alanlarının görsel peyzaj kalitesini & bitkiler doğa ile uyumludur" verilen puan ortalaması \\
belirlemek amacıyla kullanıcılar ile anket çalışması & 0,60 'dır. Kullanıcı kokulu süs bitkilerinin bitkisel \\
yapmışlar ve beğeni faktörlerine en çok etki eden & tasarımların istenilen düzeyde olmadığını \\
peyzaj özelliğinin doğallık olduğunu belirtmişlerdir. & düşünmektedirler. Elde edilen veriler Yazici ve \\
Araştırma sonucuna göre yaya alanlarının görsel & Gülgün Aslan (2017) yaptıkları çalışmada Tokat \\
peyzaj kalitesinden memnuniyet orta seviyede & kentinde bitkisel tasarım ve bitki çeşitliliğindeki \\
olduğu tespit edilmiş ve bakım çalışmalarına önem & mevcut durumunda eksik olduğu sonucunu \\
verilmesi gerektiği vurgulanmıştır. Yeşilırmak & desteklemektedir (Çizelge 3). 57. sorusuna \\
Tokat'ta merkez kısmından geçen bölümünde yapılan & "Yeşilırmak kenarındaki rekreasyonel alanlarda zemin \\
ıslah çalışmaların kullanıcı tarafından olumlu görüş & düzgün bir yürüyüş için uygundur " verilen ortalama \\
aldığı görülmektedir. Su öğesinin kullanıcı için & puan
\end{tabular}
memnuniyet verdiği 47. soru ile ortaya çıkmıştır. 51.

Çizelge 3. Tokat Yeşilırmak kenarındaki rekreasyonel alanlara ait soruların değerlendirilmesi (devamı)

\begin{tabular}{|c|c|c|c|c|}
\hline \multicolumn{3}{|c|}{ Tokat Yeşilırmak kenarındaki rekreasyonel alanlara ait soruların değerlendirilmesi } & ทे & ذั่ \\
\hline & 48 & $\begin{array}{l}\text { Yeşilırmak kenarındaki rekreasyonel alanların eski haline göre suyu daha } \\
\text { temizdir. }\end{array}$ & 1.26 & 0.76 \\
\hline \multirow{7}{*}{$\begin{array}{l}\text { BITKI VE YABAN } \\
\text { HAYATI }\end{array}$} & 49 & $\begin{array}{l}\text { Yeşilırmak kenarındaki rekreasyonel alanlarda kullanılan bitki sayısı } \\
\text { yeterlidir. }\end{array}$ & 1.23 & 0.28 \\
\hline & 50 & Yeşilırmak kenarındaki rekreasyonel alanlardaki bitkiler bakımlıdır. & 1.12 & 0.46 \\
\hline & 51 & $\begin{array}{l}\text { Yeşilırmak kenarındaki rekreasyonel alanlarda bitkiler doğa ile } \\
\text { uyumludur. }\end{array}$ & 1.10 & 0.60 \\
\hline & 52 & $\begin{array}{l}\text { Yeşilırmak kenarındaki rekreasyonel alanlarda renk ve koku özelliği } \\
\text { gösteren bitkilere yer verilmiştir. }\end{array}$ & 1.20 & 0.20 \\
\hline & 53 & $\begin{array}{l}\text { Yeşilırmak kenarındaki rekreasyonel alanlardaki bitkilerde doku ve şekil } \\
\text { çeşitliliği vardır. }\end{array}$ & 1.12 & 0.26 \\
\hline & 54 & $\begin{array}{l}\text { Yeşilırmak kenarındaki rekreasyonel alanlarda meyve ve çiçek güzelliği } \\
\text { gösteren bitkiler bulunmaktadır. }\end{array}$ & .24 & 0.10 \\
\hline & 55 & $\begin{array}{l}\text { Yeşilırmak kenarındaki rekreasyonel alanlarda eskisine göre farklı bitkisel } \\
\text { tasarımlar kullanılmıştır. }\end{array}$ & 1.22 & 0.20 \\
\hline \multirow{7}{*}{$\begin{array}{l}\text { GÜVENLIK, KONFOR } \\
\text { ve UYGUNLUK }\end{array}$} & 56 & Yeşilırmak kenarındaki rekreasyonel alanlarda güvenlik birimi vardır. & 1.14 & -0.21 \\
\hline & 57 & $\begin{array}{l}\text { Yeşilırmak kenarındaki rekreasyonel alanlarda zemin düzgün bir yürüyüş } \\
\text { için uygundur. }\end{array}$ & 1.18 & 0.65 \\
\hline & 58 & $\begin{array}{l}\text { Yeşilırmak kenarındaki rekreasyonel alanlarda toplu kullanıma uygun } \\
\text { yeterli alan bulunmaktadır. }\end{array}$ & 1.19 & 0.37 \\
\hline & 59 & $\begin{array}{l}\text { Yeşilırmak kenarındaki rekreasyonel alanlarda kullanılan yapı ve } \\
\text { malzemelerin ölçütleri tüm kullanıcı grupları (engelli/çocuk/yaşlı) için } \\
\text { uygundur. }\end{array}$ & 1.13 & 0.39 \\
\hline & 60 & $\begin{array}{l}\text { Yeşilırmak kenarındaki rekreasyonel alanlarda kullanılan donatılar } \\
\text { kullanım açısından konforludur. }\end{array}$ & 1.12 & 0.31 \\
\hline & 61 & $\begin{array}{l}\text { Yeşilırmak kenarındaki rekreasyonel alanlarda çocuklar için yeterli } \\
\text { güvenlik (suya düşme tehlikesi) önlemleri alınmıştır. }\end{array}$ & 1.36 & -0.11 \\
\hline & 62 & $\begin{array}{l}\text { Yeşilırmak kenarındaki rekreasyonel alanların yeni hali kullanılabilirliği } \\
\text { artırmıştır. }\end{array}$ & 1.05 & 0.96 \\
\hline \multicolumn{5}{|c|}{$\begin{array}{cl}\text { Sonuç ve Öneriler } & \text { Değişen dünya ile birlikte kullanıcı memnuniyeti ve } \\
\text { Kentsel alanda yeşil alanlarda kullanılan } & \text { rekreasyonel alanlarda oluşan beklentiler de } \\
\text { elemanların kullanılabilirlik kriteri açısından ve } & \text { değişmektedir. Günümüz yeşil alanları hem kent } \\
\text { modern dünya yaşam stillerine bağlı olarak sürekli } & \text { kimliğini olumlu yönde etkilemeli de kullanıcının aktif } \\
\text { güncellenmesi gerekmektedir (Düzenli ve ark., 2017). } & \text { ve pasif kullanım alanlarını içinde barındırmalıdır. }\end{array}$} \\
\hline
\end{tabular}


Yapılan çalışmada kullanıcıların demografik yapıları incelendiğinde; kullanıcıların yüzde 51,3 kadın ve $\% 48,7$ 'si erkektir. Ankete katılan kullanıcıların eğitim durumu ise; 57 kişi ilköğretim, 102 kişi lise, 190 kişi üniversite ve 35 kişi lisansüstü eğitimi görmüştür. Bilgi düzeylerinin sorulara verdikleri cevaplar ile ilişkilendirildiğinde bazı sorularda (bkz. Çizelge 4) anlamlı farklılar olduğu görülmektedir. Konum ve ulaşılabilirlik gruplarındaki sorulara verilen puanlama ortalamanın $(0,60)$ üzerinde olmuştur. Kullanıcıların puanlamasına göre; Yeşil ırmak kenarında meydana gelen manzaranın gün boyunca canlı olduğunu düşünmektedirler. Irmak kenarının ziyaret edilebilecek nitelikte olması, restorasyon çalışması ile yeni hali tarihi objelerin görsel kalitesini arttırdığı verilen puanın ortalaması ortaya çıkmıştır. Arazi plastiği peyzaj öğesinde; kullanıcıların 22. soruda verdikleri puan değerlendirildiğinde merdiven ve rampalardan memnun değillerdir. Sınır öğesi grubunda kullanıcılara sorulan 23. sorunun puan ortalaması "Yeşilırmak kenarındaki rekreasyonel alanları sınırlayan yapısal peyzaj elemanları vardır" kıstas alınan memnuniyet ortalamasından düşüktür. Rekreasyonel alanı kullanıcıların etkinlik mekanlarda 24, 28 ve 29.u sorular değerlendirilen memnuniyet ortalamanın üstünde puan vermişlerdir. Kullanıcılar klimatik faktörlere göre uygun malzeme kullanılmadığını düşünmektedir.

Ayrıca kullanıcı kokulu süs bitkilerinin bitkisel tasarımların istenilen düzeyde olmadığını düşünmektedirler. Yeşilırmak'ta yapılan ıslah çalışmasından dolayı suyun kalitesinin artırdığı, su öğelerinin parkın prestijini artırdığını düşünmektedirler.

Kentsel peyzajda önemli yeri olan yeşil alanların kullanım amaçlarını doğru yansıtması gerekmektedir. Bitki seçimi, donatı elemanları gibi yeşil alanların alt yapısını oluşturan malzemelerin iklimsel faktörlere uygunluğu kullanıcı memnuniyeti olumlu etkilemektedir.

Elde edilen sonuçlarda; Yeşilırmak yakın çevresinde yer alan peyzaj öğelerini değerlendiren kullanıcıların su öğesinden memnun oldukları ortaya çıkmıştır. Uygun alan seçimi peyzaj planlamada en temel unsurlardan biridir. Kullanıcılar rekreasyonel alanların konumundan ve ulaşılabilirliğinden memnun olduğu ortaya çıkmıştır. Yapılan bu çalışma ile kullanıcıların tercihlerinde düşük ortalamaya sahip olan peyzaj öğelerine şu öneriler getirilebilir:

- Rekreasyonel alanlarında donatı elemanlarının uygun malzemelerden seçilmesi,

\begin{abstract}
- Donatı elemanları seçiminde klimatik faktörlerin göz önünde bulundurulmalı,

- Sınır elemanlarının Yeşilımak yakın çevresinde kullanımının arttırılmalı,

- Güvenlik personellerinin Yeşilırmak yakın çevresinde belirli noktalarda bulundurulmalı,

- Yeşilırmak yakın çevresine çocukların düşmesini engelleyecek yapısal elemanların arttırılmalı (Taş Köprü yakın çevresi),
\end{abstract}

- Donatı elemanlarında genel uyum sağlanması(Örn: bank, pergola, aydınlatma elemanı ve çöp kovasının uyumlu malzemelerden yapılmalı,

- Tercih edilen sert zeminlerin malzemelerinin kış mevsiminde kaymayı engelleyici özellikte olmalı,

- Bitkisel ve yapısal (cansız) elemanların bakımının düzenli yapılmalı,

- Çocuk oyun üniteleri arttırılmalı.

Kent peyzajında aktif yeşil alanlar önemli rol oynamaktadır. Tokat'ta incelenen rekreasyonel alan kullanıcılarının profili ve memnuniyeti anketi sonucunda elde edilen verilerin sürdürülebilir peyzaja katkı sağlayacağı düşünülmektedir. Ayrıca bu çalışma Tokat kentinde yapılacak rekreasyonel alan projelerine rehber niteliği taşıyacaktır.

\section{Kaynaklar}

Aksu, A., Yılmaz, H. 2018. Atatürk Üniversitesi Merkezi açık-yeşil alandaki fiziki değişim memnuniyetinin belirlenmesi. Iğdır Üni. Fen Bilimleri Enst. Der., 8(2): 231-237.

Alpay, M.O., Kalaycı, A., Birişçi, T. 2013. Ekolojik tasarım kriterlerine göre kent parkı iyileştirme modeli: İzmir Kültürpark örneği, TMMOB 2. İzmir Kent Sempozyumu / 28-30 Kasım 2013.

Anonim, 2018. Tokat Belediyesi Resmi Web Adresi. www.tokatbel.tr.

Arıkan, R. 2004. Araştırma Teknikleri ve Rapor Hazırlama. Ankara: Asil Yayın.

Asur, F. 2019. An evaluation of visual landscape quality of coastal settlements: A Case study of coastal areas in the Van Lake basin (Turkey). Applied Ecology and Environmental Research, 17(2): 1849-1864.

Aşur, F., Alphan, H. 2017. Van Gölü Güney Kıуı alanlarında yerleşim alan kullanım değerlendirmesi ve görsel analiz 
yaklaşımları. Iğdır Üniversitesi Fen Bilimleri Enstitüsü Dergisi, 7(4): 223-233.

Berber, B., Edgü, E., 2016. Kütahya'nın sosyal ve kültürel değişiminin kent mimarisine etkisi. Erciyes Üniversitesi Mimarlık Fakültesi IV. Çevre-Tasarım Kongresi 2016. 05-06 Mayıs 2016, Kayseri, s. 363-374.

Birişçi, T. 2012. Ekolojik Bir Sorun Olarak Işık Kirliliği. Peyzaj Ekolojisi Ders Notu, Ege Üniversitesi, Ziraat Fakültesi, Peyzaj Mimarlığı Bölümü.

Bowes, S., Dawson, C.P. 1998. Watercraft User Motivations, Perceptions of Problems, and Preferences for Management Action: Comparisons between Three Levels of Past.

Dawson, C.P., Newman, P., Watson, A. 1997. Cognitive Dimensions of Recreational User Experiences in Wilderness: An Exploratory Study in Adirondack Wilderness Areas. Proceedings of the 1997 Northeastern Recreation Research Symposium. New York. GTR-NE-241., pp: 257-259.

Düzenli, T.T., Eren, E., Alpak, E.M. 2017. Müze bahçelerinin peyzaj özellikleriyle kullanıcı memnuniyeti ilişkisi. International Periodical for the Languages, Literature and History of Turkish or Turkic., 12(13): 201-214.

Erdoğan, R., Oktay, H.E., Yıldırım, C. 2011. AntalyaKonyaaltı Parklarında kullanılan donatı elemanları tasarımlarının kullanıcı görüşleri doğrultusunda değerlendirilmesi. Artvin Çoruh Üniversitesi Orman Fakültesi Dergisi, 12(1): 18.

Gülgün, B., Güney, M., A., Aktaş, E., Yazici, K. 2014. Role of Landscape architect in interdisciplinary planning of sustainable cities. Journal of Environmental Protection and Ecology, 15(4): 1877-1880.

Gülgün B., Sayman, M., Yazici K. 2015. Recreational habit of Izmir metropolitan residents and their association with natural parks around the town. J. Int. Environmental Application \& Science, 10(3): 367-374.

Kart, N. 2005. Emirgan Parkı'nda kullanıcıların memnuniyet derecelerinin değerlendirilmesi. İstanbul Üniversitesi Orman Fakültesi Dergisi, 55(1): 184-208.

Müderrisoğlu, H., Demir, Z. 2004. The relationship between perceived beauty and safety in urban recreation parks. Journal of Applied Sciences, 4 (1): 72-77.

Müderrisoğlu, H. 2002. Mekânda kalabalık algısı ve kullanıcı memnuniyeti. İstanbul Üniversitesi Orman Fakültesi Dergisi, 52(1): 124-131.
Uzun, F. 2019. Rekreasyon Faaliyetlerinin Engellilerde Yeri ve Önemi (Down Sendromu Üzerine Nitel Çalışma). Yayınlanmamış Yüksek Lisans Tezi. Batman Üniversitesi Sosyal Bilimler Enstitüsü, Batman.

Tarakci, E.E., Düzenli T., Akyol, D. 2017. Examination of Museum Garden Landscape Plans in Terms of Socio-Cultural Sustainability: The Example of Trabzon City, in: Ecology, Planning and Design. Koleva, I., Yüksel, U.D., Benaabiadate, L., Eds., St. Kliment Ohridski University Press, Sofia, pp. 502-514.

Tilt, J.H. 2009. Walking trips to parks: Exploring demographic, environmental factors, and preferences for adults with children in the household. Publisher: Elsevier Inc., Preventive Medicine, 50(1): 69-S73.

Topalfakıoğlu, G.C. 2002. Üsküdar İlçesi'ndeki Yeşil Alanların Kullanımının ve Kullanıcıların Memnuniyet Derecelerinin Değerlendirilmesi: Büyük Çamlıca Korusu, Fethi Paşa Korusu ve Doğancılar Parkı. İstanbul Teknik Üniversitesi, Fen Bilimleri Enstitüsü, Yüksek Lisans Tezi, s. 116-119.

Türkiye İstatistik Kurumu, 2018. Resmi web sitesi: www.tuik.gov.tr

Whittaker, D., Shelby, B. 1988. Types of norms for recreation impacts: Extending the social norms concept. Journal of Leisure Research, 20(4):.

Vural, H., Yılmaz, S. 2018. Ortaokul Öğrencilerinin mekâna bağlı serbest zaman aktivite tercihleri ve rekreasyonel eğitimleri. Türk Tarım ve Doğa Bilimleri Dergisi, 5(4): 424-432. http://dergipark.gov.tr/turkjans/issue/39809/ 471208.

Yazici, K., Gülgün Aslan, B. 2017. Açık-yeşil alanlarda dış mekân süs bitkilerinin önemi ve yaşam kalitesine etkisi; Tokat kenti örneği. Ege Üniv. Ziraat Fak. Derg., 54(3):2 75-284, ISSN 10188851.

Yazici, K. 2018. Evaluation of visual landscape quality in the wetlands North of Sivas (Turkey). Applied Ecology and Environmental Research, 16(4): 4183-4194.

Yazıcıoğlu, Y., Erdoğan, S. 2004. SPSS Uygulamalı Bilimsel Araştırma Yöntemleri. Ankara: Detay Yayıncılık.

Yılmaz, H., Irmak, M.A. 2012. Yerleşke Planlamasında Bitkisel Tasarım Illkeleri; Atatürk Üniversitesi Yerleşkesi Örneği. Atatürk Üniv. Yayın No: 1011, Erzurum, Türkiye. $192 \mathrm{~s}$. 